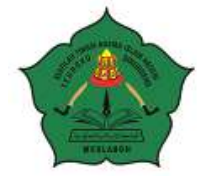

AT-TASYRI' Jurnal Ilmiah Prodi Muamalah

P-ISSN: 2085-2541, E-ISSN: 2715-7865

Volume 13, Nomor 2, Desember 2021

https://ejournal.staindirundeng.ac.id/index.php/Tasyri

\title{
PEMBERDAYAAN EKONOMI MASYARAKAT ACEH DI MASA PANDEMI COVID-19 MELALUI MASJID
}

\author{
Kamaruddin \\ Fakultas Dakwah dan Komunikasi UIN Ar-Raniry Banda Aceh \\ kamaruddin@ar-raniry.ac.id
}

\begin{abstract}
Abstrak
Peran masjid sebagai pusat aktivitas ekonomi tidak dapat dilepaskan dari eksistensi masjid dari aspek historinya. Namun realitanya, masjid-masjid di Aceh selama ini hanya menjalankan fungsi sebagai tempat pelaksanaan ibadah mahdhah dan pusat pendidikan Islam non-formil. Sementara itu, fungsi masjid sebagai penggerak kegiatan sosial dan ekonomi umat kurang mendapat perhatian dari pengelola masjid, terlebih lagi di masa pandemi COVID-19 seperti saat ini. Artikel mengkaji lebih lanjut tentang bagaimana strategi pemberdayaan ekonomi masyarakat Aceh di masa pandemi COVID-19 melalui masjid. Kajian ini menggunakan jenis penelitian kualitatif deskriptif analitik, dengan menerapkan metode penelitian lapangan. Berdasarkan penelitian yang dilakukan dapat dikemukakan bahwa kendala utama yang dihadapi masyarakat miskin dalam meningkatkan ekonomi keluarga sangat berkaitan dengan kemampuan mereka dalam mengakses permodalan. Pemberdayaan ekonomi masyarakat melalui masjid merupakan salah satu cara yang dapat digunakan untuk mengurangi angka kemiskinan di Aceh di masa pendemi COVID-19. Masjid yang selama ini melaksanakan perannya sebagai tempat beribadah mahdhah semata, memiliki potensi sebagai institusi yang dapat memberikan pinjaman modal kepada jamaah dan masyarakat miskin yang tinggal di sekitar masjid. Program pemberdayaan ekonomi masyarakat melalui masjid, perlu menjadi program prioritas bagi seluruh masjid di Aceh.
\end{abstract}

Kata Kunci: Pemberdayaan Ekonomi, Masjid, Aceh, Covid-19

\begin{abstract}
The role of the mosque as a center of economic activity cannot be separated from the existence of the mosque from its historical aspect. However, in reality, mosques in Aceh have only functioned as a place for the implementation of mahdhah praying and a center for non-formal Islamic education. Meanwhile, the function of mosques as a stimulus of social and economic activities for peoples who has received not enough attention from man who manage the mosques, especially during the COVID-19 pandemic. This article talk about how the economic empowerment strategy of the Acehnese people during the COVID-19 pandemic through mosques. This study uses an analytical descriptive qualitative research type, by taking field research methods. Based on the research, the conclusion which is found that the main problem faced by the poor people in improving the family economy is closely related to their ability to get source of funds. The community of economic empowerment through mosques is one way that can be used to reduce poverty in Aceh during the COVID-19 pandemic. The mosque, which has been carry out its role as a mahdhah praying place, has the potential as an institution that can provide source of funds loans to poor people who live around the mosque. The community of economic empowerment program through mosques needs to be a priority program for all mosques in Aceh.
\end{abstract}

Keywords: Economic Empowerment, Mosque, Aceh, Covid-19 


\section{A. PENDAHULUAN}

Pandemi virus corona (COVID-19) yang melanda dunia sejak setahun lalu, telah mempengaruhi semua sektor kehidupan manusia, termasuk ekonomi. Hal ini kemudian juga berdampak pada perubahan sosial dan ketahanan masyarakat. Sampai saat ini, pemerintah masih terus berupaya untuk mengendalikan penyebaran virus COVID-19. Anjuran penerapan protokol kesehatan dan pembatasan ruang gerak masyarakat secara ketat, telah memberi pengaruh terhadap laju perekonomian yang berdampak pada tingkat kesejahteraan sosial masyarakat, dengan tingkat kemiskinan yang semakin tinggi. Di masa pandemi COVID-19, banyak masyarakat harus rela kehilangan pekerjaan. Jika pun ada usaha yang dijalankan masyarakat untuk memenuhi kebutuhan keluarga, usaha tersebut mengalami stagnan, ada pula yang gulung tikar. Bahkan kondisi sosial ekonomi masyarakat di tengah pandemi, akan semakin diperparah tanpa adanya bantuan sosial dari pemerintah.

Banyak pihak yang mempertanyakan kebijakan pemerintah dalam penanganan COVID-19, karena dianggap tidak memiliki arah yang jelas dan tanpa mempertimbangkan aspek secara menyeluruh terhadap efek yang ditimbulkan oleh COVID-19. Pada masa awal penanganan COVID-19 di Indonesia, Aceh termasuk salah satu daerah dengan kasus penularan terendah dibanding daerah lainnya. Hanya saja, fokus Pemerintah Aceh kala itu masih pada upaya memutus mata rantai penyebaran virus COVID-19, sebagaimana halnya kebijakan secara nasional, masih abai terhadap pemberdayaan masyarakat sebagai imbas pandemi yang sedang berlangsung. Akibatnya, ketika kasus penularasan COVID19 di Aceh mengalami lonjakan, Pemerintah
Aceh mulai kalang kabut. Hingga akhirnya ikut menerapkan pembatasan ruang gerak masyarakat, seperti daerah-daerah lain di Indonesia. Dimana hal ini kemudian memunculkan protes dari masyarakat, terutama mereka yang tidak bisa bekerja untuk memenuhi nafkah keluarga. Sementara pemerintah tidak mampu memberikan jaminan apa-apa untuk keberlangsungan ekonomi dan hidup masyarakat.

Kondisi ini tentunya akan mampu diminimalisir, jika Pemerintah Aceh mampu melihat alternatif lain terkait pemberdayaan ekonomi masyarakat. Salah satunya, melalui pengelolaan manajeman masjid yang berbasis pada pemberdayaan ekonomi umat. Konsep ini akan sangat membantu dalam memperkuat berbagai program perlindungan sosial untuk menangani krisis selama pandemi COVID 19. Program-program pemberdayaan yang dilakukan melalui masjid, akan melindungi masyarakat miskin dan masyarakat yang berpenghasilan menengah ke bawah dari guncangan ekonomi, sehingga mampu bertahan di tengah himpitan pandemi COVID-19.

Pemberdayaan ekonomi umat melalui masjid merupakan usaha peningkatan kemampuan dan sumber daya yang dimiliki masjid untuk menjaga keberlangsungan masjid, serta meningkatkan kesejahteraan masyarakat dan jamaah. Dari aspek historis, keberadaan masjid tidak dapat dilepaskan dari perannya sebagai pusat aktivitas ekonomi. Fakta historis menunjukkan bahwa, masjid tidak hanya berfungsi sebagai pusat aktivitas spiritual keagamaan dalam bentuk pelaksanaan ibadah mahdhah semata, tetapi juga berperan dalam aspek pendidikan, sosial, politik, ekonomi, dan sebagainya. ${ }^{1}$ Pada masa

\footnotetext{
${ }^{1}$ Baca Johan H. Meuleman, 2002, (ed.) Islam in the Era Globalization: Muslim Attitudes Towards Modernity and Identity, (London: Routledge, 2002) dan Mohammad Tajuddin Haji Mohammad Rasdi, The Mosque as a Community Development Centre: Programme and Architectural Guidelines for Contemporary
} 
Nabi Muhammad SAW, masjid menjadi pusat segala aktivitas dalam rangka pembangunan umat Islam. Masjid mempunyai nilai strategis bagi umat Islam untuk menyelesaikan segala permasalahan, mulai dari diskusi terkait strategi perang, proses pengajaran agama Islam, penyelesaian permasalahan konflik sosial, dan juga berperan sebagai penggerak ekonomi umat Islam masa itu. ${ }^{2}$

Namun realita yang terjadi hari ini, masjid-masjid di Indonesia selama ini hanya menjalankan fungsi sebagai tempat pelaksanaan ibadah mahdhah dan pusat pendidikan Islam non-formil. Sementara itu fungsi masjid sebagai penggerak kegiatan sosial dan ekonomi umat, kurang mendapat perhatian dari takmir masjid. Sehingga tidak jarang ditemui masjid-masjid yang dibangun megah dengan ornamen-ornamen yang indah, sepi dari aktivitas umat. Bahkan banyak dijumpai, masjid hanya digunakan sebagai tempat shalat berjamaah lima waktu. ${ }^{3}$

Di Indonesia, upaya untuk menata kembali masjid yang berfungsi sebagai pusat kegiatan dakwah, pendidikan, sosial, kesehatan, dan ekonomi telah mulai dilakukan di beberapa daerah. Adapun masjid-masjid yang mulai melakukan pemberdayaan ekonomi di antaranya, masjid Jogokariyan di Yogyakarta, masjid al-Akbar di Surabaya, masjid Cut Mutia, Masjid Raya Pondok Indah, dan Masjid Jami’ Bintaro Jaya di Jakarta. ${ }^{4}$ Jika dilihat dari lingkup Aceh, gerakan pemberdayaan ekonomi melalui masjid masih belum terlihat. Padahal dengan segala keistimewaan yang dimiliki, Aceh sangat berpotensi untuk mewujudkan pemberdayaan ekonomi umat melalui masjid. Berdasarkan rekapitulasi data yang dipublis Dinas Syariat Islam tahun 2021, jumlah masjid yang melaksanakan shalat Jumat di Aceh mencapai 3.954 unit, tersebar di 23 kabupaten $/$ kota. $^{5}$

Secara umum, status masjid di Aceh terbagi dua, yaitu masjid yang pengelolaannya didukung oleh pemerintah, baik dalam hal pendanaan maupun para pengurus yang bertugas mengelola masjid. Biasanya masjid-masjid ini terletak di tengah kota dan sering dikenal dengan istilah masjid raya atau masjid jamik yang memiliki bangunan besar dan megah serta pengurus takmir masjid mendapat insentif dari pemerintah. Ada juga masjid yang didirikan untuk keperluan tempat ibadah pegawaipegawai perkantoran, tetapi masjid tersebut hanya melakukan aktivitas shalat berjamaah lima waktu. Selain itu, ada juga masjid yang pengelolaannya murni swadaya masyarakat. Masjid-masjid ini biasanya terletak di kampung-kampung, dimana dari segi ukuran sangat tergantung dengan taraf hidup masyarakat sekitar.

Muslim Societies, (Johor Bahru: UTM, 1998. Lihat Cucu Nurjjamilah, 2016, "Pemberdayaan Masyarakat Berbasis Masjid dalam Perspektif Dakwah Nabi SAW”, Journal of Islamic Studies, and Humanities, Vol 1, No. 1, hal. $93-$ 119.

${ }^{2}$ Ahmad Supriyadi, 2017, "Pemberdayaan Ekonomi Berbasis Masjid (Studi Kritis Pasal 53, 54, dan 55 PP. Nomoe 14 Tahun 2014 tentang Pelaksanaan UU Nomor 23 Tahun 2011 Tentang Pengelolaan Zakat), Jurnal AnNisbah, Vol. 03. No. 02, April 2017, (p 209-229), hal. 209.

${ }^{3}$ Said Tuhuleley. Masjid, Rekonstruksi Wawasan Kemanusiaan, dan Pembangunan Ummat, Seminar Nasional Milad Masjid Syuhada, Yogyakarta, 2002. Lihat juga Kamaruddin dkk. Revitalisasi Fungsi Masjid Dalam Pemberdayaan Umat di Aceh, Studi kasus di Banda Aceh Besar, Aceh Tengan dan Aceh Tamiang. Banda Aceh: Pusat Penelitian IAIN Arraniry, 2011

${ }^{4}$ Wahu Panca Hidayat dan Puji Lestari, tt, "Strategi Pengembangan Jama'ah Masjid Jogokariyyan Yogyakarta Sejak 2003-2013"

${ }^{5}$ Abdusy Syakur. 2021, Rekapitulasi Data Masjid Yang Melaksanakan Sholat Jumat di Aceh. (Dinas Syariat Islam) diakses pada https://data.acehprov.go.id/dataset/rekapitulasi-data-masjid-yang-melaksanakan-sholatjumat-di-aceh 
Meski begitu, dana yang digunakan untuk biaya pembangunan, operasional dan pemeliharaan masjid, baik itu yang disubsidi pemerintah mahupun swadaya masyarakat, sangat bergantung dari sedekah jamaah masjid melalui tabungan amal yang sering diedarkan ketika shalat-shalat berjamaah. Jumlah tabungan amal yang diperoleh setiap masjid sangat tergantung dengan jumlah jamaah yang shalat di masjid tersebut. Selain itu juga dipengaruhi tingkat kehidupan ekonomi masyarakat yang tinggal di sekitar masjid. Jumlah total keseluruhan tabungan amal dan pengeluaran untuk pengelolaan masjid, biasanya akan diumumkan setiap Jumat. Jumlah sedekah jamaah biasanya akan mengalami peningkatan pada bulan Ramadan.

Selain itu biaya pembangunan dan operasional masjid juga diperoleh dari sumbangan-sumbangan individu masyarakat, seperti pada saat prosesi pernikahan. Tradisi masyarakat Aceh yang lebih tertarik melaksanakan prosesi pernikahan di masjid ketimbang di rumah atau Kantor Urusan Agama (KUA), telah menjadikan tabungan amal di masjid semakin bertambah jumlahnya. Akan tetapi tidak semua masjid di Aceh memiliki peluang untuk dipilih masyarakat dalam melaksanakan prosesi pernikahan. Biasanya masjid yang dipilih masyarakat untuk prosesi pernikahan adalah masjid-masjid yang terletak di perkotaan dengan bangunan megah dan indah. Sementara itu untuk masjid-masjid yang berada di kampung, biasanya pengumpulan dana untuk pembangunan dan biaya operasional, serta pemeliharaan masjid juga diperoleh melalui penggalangan dana di jalanan, dengan menempatkan drum di tengah badan jalan. Sukarelawan berdiri dengan memegang wadah sebagai tempat sumbangan para pengendara kendaraan roda dua dan empat.
Kemampuan masjid dalam mengumpulkan dana infaq dan sedekah tidak berbanding lurus dengan kompetensi pengurus takmir masjid. Selama ini, orangorang yang masuk dalam kepengurusan masjid di Aceh tidak memiliki standar tertentu terkait keahlian yang harus dimiliki dalam pengelolaan masjid. Siapa saja berpeluang untuk menjadi pengurus takmir masjid, selama dia mau meluangkan waktu untuk mengelola masjid. Hal ini kemudian berdampak pada manajemen pengelolaan masjid yang masih bersifat tradisional. Dimana masih banyak masjid yang belum memiliki pembukuan keuangan yang baik. Selain itu, sumber daya takmir masjid yang lemah juga berakibat pada upaya memakmurkan masjid lebih didasarkan pada peningkatan jumlah jamaah shalat lima waktu. Di samping itu, masjid juga dimanfaatkan sebagai tempat Taman Pendidikan Al-Qur'an (TPA), kegiatan majelis ta'lim, dan pelaksanaan hari besar perayaan agama Islam, seperti maulid, Israk Mi'raj, dan sebagainya. Masih sangat jarang ditemui masjid di Aceh yang memiliki kegiatan inovatif, seperti program pemberdayaan ekonomi umat dan masyarakat sekitar.

Padahal, jika dilihat dari kemampuan masjid dalam mengumpulkan dana infaq dan sedekah dari jamaah dan masyarakat sekitarnya, seharusnya masjid berpotensi untuk dijadikan sebagai motor penggerak pemberdayaan masyarakat di Aceh. Oleh karena itu, kompetensi sumber daya takmir masjid dengan kapasitas yang baik, akan berimplikasi pada manajemen pengelolaan masjid professional, transparan, dan akuntabel. Di samping itu, juga akan dapat melahirkan program-program kegiatan masjid yang kreatif dan inovatif dalam memberdayakan masyarakat. 
Penelitian ini akan mengkaji lebih dalam tentang potensi masjid sebagai motor penggerak pemberdayaan ekonomi masyarakat Aceh di masa pandemi COVID19. Penelitian ini diharapkan dapat memberikan gambaran tentang rumusan strategi dan model yang sesuai untuk pemberdayaan ekonomi masyarakat Aceh di masa pandemi COVID-19. Permasalahan kajian ini dibatasi pada upaya revitalisasi fungsi masjid sebagai motor penggerak pemberdayaan ekonomi masyarakat Aceh, dengan cara menganalisis potensi masjid sebagai wadah pemberdayaan ekonomi umat, baik dari aspek ekonomi maupun sosial. Adapun yang dijadikan sumber dianalisis adalah masjid-masjid yang terletak di kota, dengan jamaah yang ramai dan terdapat aktivitas sosial-keagamaan.

\section{B. KAJIAN PUSTAKA}

\section{Pemberdayaan Ekonomi}

Istilah pemberdayaan pertama kali diperkenalkan oleh aktivis Gerakan Black Panther dalam mobilisasi politik di USA pada tahun 1960-an atas respon isu kala itu. Pemberdayaan ekonomi masyarakat merupakan salah satu program yang bertujuan untuk mengurangi angka kemiskinan. Kesulitan yang selama ini dialami masyarakat miskin adalah akses terhadap permodalan. Sementara motivasi mereka untuk dapat hidup sejahtera cukup tinggi, namun tidak diimbangi oleh kemudahan mereka dalam memperoleh pinjaman modal usaha. Dengan berbagai instrumen yang dimilikinya, masjid telah memberi peluang bagi munculnya program-program pemberdayaan ekonomi masyarakat. Masjid memiliki potensi yang signifikan, seperti dana yang banyak melimpah dari para jamaah. ${ }^{7}$ Hal ini semestinya dapat digunakan dalam rangka pemberdayaan ekonomi umat sekitar masjid. Upaya pemberdayaan untuk menumbuhkan aktivitas ekonomi masyarakat melalui masjid, akan menciptakan hubungan timbal balik antara masyarakat dengan masjid.

Secara konsep, para peneliti memiliki pandangan berbeda tentang makna pemberdayaan. Istilah pemberdayaan memiliki makna yang beragam dalam berbagai konteks. Misalnya saja, ketika istilah pemberdayaan digunakan dalam wilayah kajian sosial budaya atau ekonomi, akan berbeda dengan bidang politik. Begitu pun tema pemberdayaan, selalu memiliki arti yang lebih fleksibel dan mengandung elemenelemen yang terdiri dari kekuatan diri, kontrol, kemandirian, pilihan sendiri, kehidupan yang bermartabat sesuai dengan nilai-nilai seseorang, mampu memperjuangkan hak, kemandirian, pengambilan keputusan sendiri, Definisidefinisi ini tertanam dalam sistem nilai dan kepercayaan lokal ${ }^{8}$

Pemberdayaan masyarakat tidak dapat dijalankan tanpa memperhatikan potensi dari sumber daya manusia yang ada, karena sumber daya manusia inilah yang akan dijadikan sebagai subjek yang paling vital dalam pelaksanaan pemberdayaan masyarakat. Setidaknya ada tiga jenis kekuatan yang patut diperhatikan dalam upaya pemberdayaan masyarakat ditinjau dari

\footnotetext{
${ }^{6}$ Maisaroh, S., \& Sukhemi, S. (2011). Pemberdayaan Masyarakat Melalui Pengembangan Budaya Kewirausahaan Untuk Mengurangi Pengangguran Dan Kemiskinan. JEJAK: Jurnal Ekonomi Dan Kebijakan, 4(1), 23-33. https://doi.org/10.15294/JEJAK.V4I1.4638

${ }^{7}$ Azhar bin Abdul Wahab, "Financial Management of Mosques in Kota Setar District: Issues and Challenges”, Tesis, Kedah: Universiti Utara Malaysia, 2008, hal. iii.

${ }^{8}$ World Bank. (2001). What Is Empowerment? Development, (Unicef), hal. 10
} 
potensi sumber daya manusianya, antara lain":

a. Kekuatan Pendorong (motivational forces). Dicirikan dengan orang-orang yang tidak merasa puas dengan kondisi yang selama ini mereka hadapi, dan masih mempunyai perasaaan adanya sesuatu yang belum dimiliki secara kejiwaan.

b. Kekuatan Bertahan (resistance forces). Kekuatan ini bertujuan mempertahankan sesuatu yang telah ada di masyarakat, antara lain sikap apatis, tidak mudah percaya terhadap pihak luar. Rasa takut yang berlebihan dan cenderung suka mempertahankan apa yang sudah dimiliki saat ini.

c. Kekuatan Pengganggu (interference forces). Kekuatan ini muncul karena dalam suatu masyarakat akan ada kelompok-kelompok yang saling bersaing untuk mendapatkan dukungan dalam proses pembangunan. Umumnya kekuatan ini menginginkan ketidakkompakan atau perpecahan.

Sementara itu, dalam pelaksanaan pemberdayaan masyarakat di lapangan, ada tiga pandangan yang dapat digunakan untuk memandirikan dan mensejahterakan masyarakat. ${ }^{10}$ Pandangan pertama, pemberdayaan adalah penghancuran kekuasaan atau power to nobody. Pandangan ini didasari oleh keyakinan, bahwa kekuasaan telah mengisolasi dan menghancurkan manusia dari eksistensinya. Oleh karena itu, untuk mengembalikan eksistensi manusia dan menyelamatkan manusia dari keterpencilan dan penindasan, maka kekuasaan harus ditiadakan.
Pandangan kedua, pemberdayaan adalah pembagian kekuasaan kepada setiap orang (power to everybody). Pandangan ini didasarkan pada keyakinan, bahwa kekuasaan yang terpusat akan menimbulkan kezaliman dan cenderung mengalienasi hak normatif manusia yang tidak berkuasa atau yang dikuasai. Oleh sebab itu, kekuasaan harus didistribusikan ke semua orang, agar semua orang dapat mengaktualisasikan dirinya sendiri. Pandangan ketiga, pemberdayaan adalah penguatan kepada yang lemah tanpa menghancurkan yang kuat. Pandangan ini adalah pandangan yang paling moderat dari dua pandangan lainnya. Pandangan ini merupakan sintesa dari pandangan power to nobody dan power to everybody. Menurut pandangan ini, Power to nobody adalah suatu kondisi yang mustahil dilaksanakan. Sedangkan pendekatan power to everybody akan dapat menimbulkan chaos dan anarki. Oleh karena itu, pendekatan yang paling sesuai dan realistis adalah power to powerless. ${ }^{11}$

Ada banyak strategi yang telah dipraktekkan oleh pemerintah, masyarakat sipil dan sektor swasta terkait inisiasi pemberdayaan masyarakat miskin. Dimana indikator kesuksesan suatu kegiatan pemberdayaan masyarakat dalam berbagai konteks dapat dilihat, ketika masyarakatnya sudah memiliki sikap bebas memilih dan bertindak. Ada empat unsur penting yang harus diperhatikan pada setiap kegiatan pemberdayaan masyarakat yaitu, akses

${ }^{9}$ Lucie Setiana, 2005, Teknik Penyuluhan dan Pemberdayaan Masyarakat, (Jakarta: Ghalia Indonesia)

${ }^{10}$ Pemberdayaan: Konsep, kebijakan dan implementasi. Onny S. Prijono dan A.M.W Pranarka (penyunting); 1996; hal. 45-70. CSIS; Jakarta

${ }^{11}$ Hutomo, M. Y. (2000). Pemberdayaan Masyarakat dalam Bidang Ekonomi: Tinjauan Teoritik dan Implementasi. Naskah, 20 (20), hal.1-11. 
terhadap informasi, inklusi dan partisipasi, akuntabilitas dan kapasitas organisasi lokal. ${ }^{12}$

\section{Fungsi Masjid}

Mayoritas muslim memahami bahwa masjid adalah tempat melaksanakan shalat dan ibadah lainnya. Bahkan bagi sebagian muslim, memahami masjid sebagai tempat menunaikan shalat Jumat. Padahal masjid memiliki makna yang luas, bukan hanya sebagai tempat melaksanakan ibadah mahdhah. Dilihat dari segi harfiah istilah masjid berasal dari Bahasa Arab yang merupakan isim makan dari kata sajada yasjudu - sujudan - masjidun, yang berarti tempat orang sujud. Secara Bahasa, sujud berarti patuh, taat, serta tunduk dengan hormat dan takzim. ${ }^{13}$

Meskipun dalam pengertian sehari-hari masjid merupakan bangunan tempat kaum muslim shalat atau bersujud, namun sebenarnya tempat shalat atau sujud umat Islam sangat luas seluas hamparan bumi. Nabi Muhammad SAW menerangkan kepada Jabir bin Abdullah Al-Ansary bahwa "Bumi ini bagiku suci bersih dan boleh dijadikan tempat untuk shalat, maka dimanapun seorang berada bolehlah ia shalat apabila waktunya tiba." (HR. Muslim,316). Hadis ini mengandung makna kewajiban muslim untuk menunaikan ibadah shalat ketika tiba waktunya dimana saja ia berada, dengan syarat tempat atau ruang untuk shalat keadaannya bersih dan suci. Hal ini menunjukkan bahwa masjid bukan hanya bangunan tempat shalat kaum muslim. Sebagaimana pendapat Quraish Shihab yang mengatakan bahwa, hakikat masjid adalah tempat melakukan segala aktivitas yang mengandung kepatuhan kepada Allah sesuai dengan akar katanya mengandung makna sujud. ${ }^{14}$

Pendapat tersebut kemudian diperkuat oleh Gazalba yang mengatakan bahwa, masjid sebagai tempat shalat adalah fungsi kedua karena jagat raya di luar masjid sangat luas, yang berfungsi sebagai masjid. Berdasarkan fakta historis, Nabi Muhammad SAW mendirikan masjid setelah 12 tahun menjalankan tugas kerasulan di Mekkah. Pembangunan masjid justru dilakukan Nabi ketika melakukan perjalanan hijrah ke Madinah. ${ }^{15}$

Pada masa Rasulullah, fungsi masjid sebagai pusat aktivitas umat Islam yang tidak hanya terbatas pada ritual shalat berjamaah, melainkan juga berfungsi sebagai tempat musyawarah untuk menyelesaikan berbagai masalah sosial. Adapun beberapa fungsi masjid pada masa Rasulullah SAW ${ }^{16}$ :

a. Tempat ibadah umat Islam, seperti shalat, zikir, dan sebagainya. Masjid pada masa Rasulullah berfungsi untuk pelaksanaan shalat fardhu lima waktu, shalat Jumat, shalat sunat berjamaah, berzikir dan ibadah lainnya.

b. Tempat berkumpul dan berbagi informasi, pelaksanaan shalat berjamaah lima waktu sehari semalam telah menjadikan masjid sebagai tempat berkumpulnya kaum muslim yang berada di sekitar masjid. Pertemuan itu dapat dijadikan sebagai sarana berbagi informasi terkait hal-hal penting yang menyangkut hidup masyarakat muslim. Peristiwa yang berhubungan kesatuan

${ }^{12}$ World Bank. (2001). What Is Empowerment? Development, (Unicef), hal. 10

${ }^{13}$ M. Quraish Shihab (1996), Wawasa Al-Qur'an, Bandung: Mizan, 1996, hal. 452.

${ }^{14}$ M. Quraish Shihab, Wawasan Al-Qur'an, hal. 453.

${ }^{15}$ Sidi Gazalba, Mesjid Pusat Ibadat, hal. 120.

${ }^{16}$ M. Quraish Shihab, Wawasan Al-Qur'an, hal. 455-456. Baca juga Sidi Gazalba, Mesjid Pusat Ibadat, hal. 126-138. Lihat juga Syahalul Kurniawan, 2014, "Masjid dalam Lintasan Sejarah Umat Islam", Jurnal Khatulistiwa-Journal of Islamic Studies, Vol. 4, No.2, hal. 169-184, hal. 174-176. 
sosial di sekitar masjid diumumkan melalui masjid.

c. Tempat pengajaran dan diskusi ilmu pengetahuan agama Islam. Nabi SAW banyak menerima wahyu dalam kurun waktu di Madinah. Segala ilmu dan pengetahuan agama Islam didiskusikan di masjid, termasuk permasalahan yang berkaitan dengan hukum dapat ditanya atau diminta penyelesaian masalahnya langsung pada Rasulullah SAW.

d. Tempat mengeluarkan fatwa untuk menyelesaikan problematikan keumatan saat itu. Problematika yang dimaksud tidak hanya berhubungan dengan persoalan agama, tetapi juga keduniawian.

e. Tempat mengadili perkara, bila terjadi perselisihan, pertengkaran, dan permusuhan diantara umat Islam.

f. Baitul mal yang dikenal dengan kas negara atau kas masyarakat muslim bertempat di masjid yang dananya digunakan untuk membiayai segala sesuatu yang menyangkut kesejahteraan kesatuan sosial Muslim.

g. Tempat penginapan musafir yang tengah dalam perjalanan.

h. Tempat menyambut tamu, rombongan, atau utusan dari berbagai wilayah di Jazirah Arab.

i. Tempat melangsungkan upacara pernikahan dan tempat mengadili perselisihan rumah tangga atau mahkamah perceraian.

j. Tempat latihan perang. Pada masa Nabi SAW, masjid berfungsi sebagai tempat latihan perang, baik itu untuk pembinaan fisik maupun mental.

k. Tempat layanan medis atau kesehatan. Rasulullah SAW menjadikan masjid

\footnotetext{
${ }^{17}$ Sidi Gazalba, Mesjid Pusat Ibadat, hal. 322.
}

sebagai tempat untuk mengobati orang sakit, khususnya pada masa perang.

Uraian di atas merupakan sebagian fungsi masjid di masa Rasulullah SAW, yang memperlihatkan bahwa masjid difungsikan sebagai tempat melayani urusan keagamaan dan keduniawian secara berimbang. Fungsi masjid sangat sesuai dengan hakikat hukum Islam yang senantiasa mengutamakan keseimbangan, seperti statis dan dinamis, takdir dan ikhtiar, spiritualisme dan materialisme, individualisme dan kolektivisme, antara ukhrawi dan duniawi dan lain sebagainya. Sehingga dapat dikatakan bahawa masjid sebagai pusat ibadah dan kebudayaan. Di mana agama bersifat serba tetap, bertujuan akhirat, karena itu masjid bersifat suci, sedangkan kebudayaan bersifat dinamis, bertujuan dunia maka masjid juga profane (duniawi). Sifat masjid yang suci dan duniawi harus berfungsi secara berimbang. Ketika terjadi peningkatan kesucian masjid, maka akan merusak keberimbangan.

Pada perkembangan selanjutnya, masjid mengalami peningkatan sifat kudusnya dibandingkan profannya. Sehingga masjid pada era kontemporer dipahami sebagai tempat ibadah dan kegiatan yang berkaitan dengan urusan akhirat semata, sedangkan soal-soal keduniawian bukan lagi di masjid tempatnya. Masyarakat muslim yang bertempat tinggal di sekitaran masjid bersatu dalam ibadah, tapi terpecah dalam kebudayaan di luar masjid. Masjid tidak lagi menjadi pusat aktivitas sosial, ekonomi, politik, ilmu, kesenian, dan filsafat, tetapi masjid hanya sebagai tempat ritualitas keagamaan. ${ }^{17}$

\section{Masjid sebagai Urat Nadi Ekonomi Masyarakat}

Menurut Mohd Yahya, Fidlizan, Mohamad, Azila, dan Nurul Fadly, peranan 
masjid dalam kehidupan umat Islam memiliki ruang lingkup yang sangat luas. Hal ini dikarenkan masjid merupakan institusi yang menyatukan seluruh umat Islam. Di antara langkah yang dapat dilakukan untuk memakmurkan masjid adalah melaksanakan aktivitas pengembangan ekonomi masjid. Oleh karena itu, masjid boleh menghasilkan secara ekonomi demi memastikan kelangsungan dan keberlanjutan aktivitas masjid, hingga memacu pembangunan ekonomi umat melalui pelibatan dalam kegiatan-kegiatan ekonomi yang produktif. ${ }^{18}$

Satu hal yang lumrah, pada awal pembangunannya, kita sering mendapati masjid berada di kawasan yang luas. Hal ini berpotensi untuk menumbuhkan aktivitas bisnis bersamaan dengan meningkatnya kunjungan jamaah masjid, baik itu karena untuk tujuan wisata religi, maupun meramaikan aktivitas sosial keagamaan di masjid. Sehubungan itu, masjid bisa menyediakan lapak bagi masyarakat di luar masjid untuk menjual aneka keperluan. Selain itu, budaya menerima sumbangan dari kalangan dermawan, mesti dijaga dengan pelbagai usaha ekonomi yang berlandaskan kewirausahaan dan perniagaan. Hal ini merupakan satu tantangan bagi masjid dalam memperjuangkan ekonomi umat, dengan tetap mengedepankan etika Islam dalam aktivitas ekonomi, terutama yang berada dalam kawasan masjid, sehingga kesucian masjid tetap terjaga.

Selain itu, masjid juga dapat menyediakan ruang atau tempat khusus untuk pungutan zakat, wakaf dan sedekah. Selain untuk memudahkan masyarakat Islam melaksanakan tanggungjawab untuk mengeluarkan zakat, kesadaran untuk bersedekah dan berwakaf juga perlu disuntik melalui ceramah-ceramah atau khutbah Jumat. Hal ini penting, karena kekayaan yang dikurniakan oleh Allah itu adalah kelebihan yang perlu dibagikan bersama dengan masyarakat Islam yang lain. Penanaman kesedaran ini sesuai dengan fungsi dan peranan masjid itu sendiri sebagai pusat ibadah dan pembangunan masyarakat. Sementara itu, ekonomi umat Islam dapat dimajukan dan diperkokoh. Di samping itu, masjid juga dapat menjadi tempat pendistribusian sumbangan dana yang didapatkan kepada pihak yang memerlukan. Dengan begitu, kehidupan ekonomi masyarakat akan lebih terjamin dan dekat dengan masjid.

\section{DATA DAN METODOLOGI}

Kajian ini merupakan jenis penelitian kualitatif, menggunakan pendekatan historis dan sosio-antropologi dalam memahami konteks pemberdayaan ekonomi masyarakat melalui masjid. Untuk mendapatkan model pemberdayaan ekonomi, peneliti menggunakan pendekatan partisipatif dengan tujuan agar model yang dihasilkan sesuai dengan keperluan masyarakat. Data-data penelitian dalam kajian ini disajikan dalam bentuk deskriptif analisis. Melalui kaedah kualitatif, diharapkan dapat mengungkapkan secara holistik potensi yang dimiliki masjid untuk memberdayakan ekonomi jamaah dan masyarakat di masa COVID-19.

Selain itu, juga dapat merumuskan strategi dan model pemberdayaan ekonomi masyarakat melalui masjid dengan pendekatan pengamatan langsung ke lapangan. Pengamatan akan diarahkan pada

\footnotetext{
${ }^{18}$ Maisaroh, S., \& Sukhemi, S. (2011). Pemberdayaan Masyarakat Melalui Pengembangan Budaya Kewirausahaan Untuk Mengurangi Pengangguran Dan Kemiskinan. JEJAK: Jurnal Ekonomi Dan Kebijakan, 4(1), 23-33. https://doi.org/10.15294/JEJAK.V4I1.4638

Wyer, P., \& Mason, J. (1999). Empowerment in small businesses. Participation and Empowerment: An International Journal, 7, 180-193. https://doi.org/10.1108/14634449910298169
} 
fenomena-fenomena umum yang terkait dengan eksistensi dan peran masjid dalam aktivitas keagamaan, sosial, dan ekonomi di masa pandemi COVID-19. Penelitian ini dilakukan di dua daerah di Aceh, yaitu Banda Aceh dan Kota Langsa. Kedua daerah ini dipilih karena memiliki kegiatan ekonomi dalam aktivitas. Disamping itu, pada masa pandemi COVID-19 dua daerah ini memiliki tingkat penularan wabah yang tinggi. Kota Banda Aceh sebagai ibu kota provinsi dan Kota Langsa daerah yang berdekatan dengan wilyah Sumatera Utara, sekaligus jalur masuk penduduk antar provinsi. Penentuan sampel penelitian dilakukan menggunakan metode porpusive sampling, dimana peneliti hanya memilih masjid-masjid dan pengelola takmir masjid berdasarkan beberapa pertimbangan yang berkaitan dengan topik penelitian.

Sumber data penelitian ini adalah primer dan data sekunder. Data primer yaitu data yang diperoleh dari lapangan yang didasarkan pada seluruh perkembangan pendapat dan pandangan yang dikemukakan oleh informan dan narasumber terkait potensi masjid sebagai penggerak pemberdayaan ekonomi bagi masyarakat di masa pandemi COVID-19. Data primer juga diperoleh melalui pengamatan langsung di lapangan terkait potensi yang dimiliki masing-masing masjid yang menjadi lokasi penelitian ini. Sementara data sekunder diperoleh melalui sumber-sumber yang berasal daripada bukubuku, artikel-artikel yang diterbitkan di jurnal yang berkenaan dengan pemberdayaan ekonomi masyarakat melalui masjid di Aceh. Data-data dalam penelitian ini dikumpulkan melalui Participation Observation, wawancara mendalam, dan studi dokumentasi.

\section{HASIL DAN PEMBAHASAN}

Beberapa masjid di Aceh memiliki potensi yang mungkin dikembangkan untuk menambah pendapatan guna mengembangkan program pemberdayaan kemandirian. Baik itu untuk biayai rutin jumatan, pembangunan dan perawatan fisik, maupun kebersihan dan keamanan masjid. Selain aktivitas tersebut, sebenarnya masih banyak kegiatan dan program yang bisa dilakukan di masjid atau sekitar masjid, sebagai bagian tidak terpisahkan dalam memfungsikan masjid sebagai kemaslahatan jamaah dan masyarakat di sekitarnya. Berbagai kegiatan itu meliputi pendidikan informal seperti TPA dan TKA di area lahan masjid yang begitu luas dan belum tergarap secara maksimal. Disamping itu, sebagian besar masjid di Banda Aceh dan Kota Langsa juga memiliki area di sekitarnya yang bisa difungsikan sebagai lahan parkir, dan lapak pedagang kecil untuk mencari nafkah.

Selain itu, masjid yang ada di Banda Aceh dan Kota Langsa juga memiliki aset properti toko yang pada umumnya disewakan kepada masyarakat untuk berdagang. Tokotoko itu ada yang terdapat di dalam area masjid, ada juga yang berada di luar masjid. Bahkan ada masjid di Kota Banda Aceh yang mengelola penginapan dan ruang pertemuan yang disewakan untuk pelatihan-pelatihan. Selain itu, sebagaimana halnya yang sedang lumrah terjadi di Aceh saat ini, masjid juga difungsikan sebagai tempat pernikahan.

Keberadaan aset milik masjid yang dikelola dengan beragam jenis bisnis ini, tentunya akan memberikan pemasukan rutin dalam jangka panjang, sehingga masjid semakin madiri dan berkembang. Namun, hal ini tidak terlepas dari kesiapan sumber daya manusia dalam mengelola potensi yang dimiliki masjid. Kemampuan pengelolaan manajemen masjid dengan segala potensi yang ada, tidak hanya memberi kemajuan bagi masjid itu sendiri, tetapi juga akan membuat kehadiran masjid benar-benar dapat dirasakan oleh masyarakat. 
Meski beberapa masjid di Banda Aceh dan Kota Langsa telah memiliki aset-aset yang dikelola dalam bentuk bisnis, namun program-program yang berkenaan dengan pemberdayaan ekonomi masyarakat masih sangat minim. Bahkan sebagian masjid masih belum memiliki wacana sama sekali tetang hal tersebut. Para pengurus masjid, masih memahami fungsi masjid hanya sebatas tempat pelaksanaan ibadah semata. Terkait hal ini, diperlukan keberanian pengurus masjid untuk melahirkan kegiatan yang terancang secara kreatif dan inovatif, serta menjadi bagian tidak terpisahkan dengan kegaitan rutin masjid lainnya.

Keberadaan masjid dengan sumber daya pengurus yang memiliki kompetensi dalam mengembangkan masjid dalam lingkup yang lebih luas, terutama berkaitan dengan pemberdayaan ekonomi masyarakat, akan membuat masjid semakin dekat dengan para jamaahnya. Dalam kondisi pandemi COVID-19 yang sedang melanda saat ini, masjid sebagai sentral aktivitas umat muslim memiliki peluang untuk mengambil peran dalam memberdayakan umat. Pengurus masjid perlu merancang upaya-upaya yang dapat meningkatkan pendapatan masyarakat, termasuk menjawab sebagian permasalahan yang dihadapi pengusaha kecil yang terimbas pandemi COVID-19. Upaya-upaya yang dilakukan dapat berupa, pelatihan/workshop bagi para pedagang kecil yang berada di sekitar kawasan masjid. Disamping itu, masjid juga dapat mengembangkan kegiatankegiatan usaha yang berdampak secara ekonomi, seperti memanfaatkan lahan sisa untuk parkir dengan memperkerjakan jamaah yang terimbas pandemi. Menyediakan lahan/lapak bagi pedagang kecil untuk memasarkan hasil produksi rumahan mereka. Selain memberi pemasukan tambahan bagi masjid, juga dapat menambah pendapatan masyarakat.
Upaya peningkatan pendapatan masjid juga bisa dilakukan dengan mebuka unit usaha yang menyediakan kebutuhan harian bagi masyarakat di sekitarnya. Misal, usaha air isi ulang untuk kebutuhan air minum yang sehat dan berkah. Bahkan jika memungkinkan, menciptakan produk air kemasan untuk mengisi kebutuhan akan produksi air mineral yang selama ini didominasi oleh perusahaan. Jika melihat potensi pasar air mineral kemasan ini, kebutuhannya sangat tinggi dan hampir ratarata didominasi oleh produk-produk luar daerah. Terobosan ini tentu harus diawali dengan pemahaman atas studi kelayakan bisnis, termasuk pelatihan kapasitas softskill, mulai dari analisa pasar, mendesain produk dan tentunya pendanaan, hingga bagaimana mengelola unit usaha agar berkelanjutan dikemudian hari.

Dari segi pembiayaan, untuk kelancaran usaha, sudah saatnya pula setiap masjid yang dianggap berpotensi dikembangakan, menghadirkan unit-unit pembiayaan ekonomi mikro. Dimana sumber pendanaannya bisa berasal dari peran serta pengusaha dan orang kaya yang berada di sekitar masjid. Namun juga tidak tertutup kemungkinan para donatur yang berada di luar kawasan masjid. Untuk pengelolaannya, harus diisi oleh orang-orang profesional, agar akuntabilitas dan transparansinya terpelihara. Sumber pendanaan ini juga bisa datang dari sedekah dan infaq jamaah.

Selain zakat yang tersalurkan secara rutin untuk konsumtif, perlu juga dicari solusi agar potensi keuangan umat bisa digunakan untuk tujuan-tujuan produktif berkelanjutan. Membuat perubahan bagi mereka yang hari ini menerima sedekah dan zakat, dikemudian hari bisa menjadi pemberi zakat. Perlu juga diajukan pemikiran untuk merangkul pihakpihak yang menjadi sumber pendanaan dari perbankan bebas riba. Pengurus masjid juga 
perlu menginisiasi untuk memperoleh dana corporate social responsibility (CSR) dari perusahaan-perusahaan besar yang beraktifitas di Aceh, agar pemberdayaan ekonomi umat dapat terwujud secara berkelanjutan, terlebih lagi di tengah kondisi pandemi COVID-19.

\section{E. KESIMPULAN}

Masyarakat Aceh, terutama pengrus masjid masih memahami masjid hanya sebatas tempat untuk melaksanakan shalat dan ibadah lainnya. Meskipun beberapa masjid di Aceh telah memiliki aset-aset yang dikelola dalam bentuk bisnis, namun pemasukan yang didapat sebagian besar hanya digunakan untuk keperluan pembiayaan rutin masjid. Seharusnya, keberadaan masjid harus mampu dikelola tidak hanya sebatas memberi kenyamanan jamaah dalam beribadah, tetapi juga dikembangkan dalam lingkup lebih luas seperti pemberdayaan ekonomi, yang bertujuan meningkatkan taraf hidup masyarakat.

Kondisi pandemi COVID-19 merupakan satu contoh kecil, dimana masjid harus hadir sebagai motor penggerak ekonomi umat. Melalui usaha-usaha produktif yang dilakukan oleh masjid, selain dapat menambah pemasukan dana untuk masjid, juga dapat memberdayakan ekonomi masyarakat, terlebih dalam kondisi pendemi COVID-19 saat ini. Untuk mewujudkan manajemen masjid yang memiliki konsep pemberdayaan, diperlukan dukungan tenagatenaga profesional yang tergabung di dalam kepengurusan setiap masjid. Kualitas sumber daya manusia pengurus masjid yang berkompeten, akan melahirkan programprogram yang kreatif dan inovatif dalam pengelolaan dan pengembangan masjid berbasis pemberdayaan ekomoni kepada masyarakat yang berkelanjutan. Selain kegiatan-kegiatan ibadah rutin, masjid juga harus mampu menjawab persoalan yang dihadapi masyarakat miskin dalam meningkatkan ekonomi keluarga, terutama berkaitan dengan kemampuan mereka dalam mengakses permodalan.

Selain itu, seluruh stakeholder, seperti tokoh masyarakat, ulama, para intelektual, serta aktivis penggerak pemberdayaan ekonomi masyarakat, juga harus dilibatkan untuk berkontribusi, baik secara konseptual maupun aksi. Pemahaman tentang fungsi masjid secara lebih luas juga perlu terus dilakukan, sehingga muncul kesadaran bersama bahwa di samping aktivitas-aktivitas ibadah, masjid juga harus dikembangkan pada hal-hal yang mampu menggerakkan masyarakat secara lebih luas. Salah satunya, melalui pemberdayaan ekonomi.

\section{DAFTAR PUSTAKA}

Syakur, Abdusy. (2021), "Rekapitulasi Data Masjid Yang Melaksanakan Sholat Jumat di Aceh". (Dinas Syariat Islam) diakses pada https://data.acehprov.go.id/ dataset/rekapitulasi-data-masjid-yangmelaksanakan-sholat-jumat-di-aceh

Supriyadi, Ahmad. (2017), "Pemberdayaan Ekonomi Berbasis Masjid (Studi Kritis Pasal 53, 54, dan 55 PP. Nomor 14 Tahun 2014 tentang Pelaksanaan UU Nomor 23 Tahun 2011 Tentang Pengelolaan Zakat)", An-Nisbah : Jurnal Fakultas Ekonomi dan Bisnis Islam, Vol. 03. No. 02, April 2017. Tulungagung : IAIN Tulungagung

Azhar bin Abdul Wahab. (2008), "Financial Management of Mosques in Kota Setar District: Issues and Challenges", Kedah: Universiti Utara Malaysia

Cucu Nurjjamilah. (2016), "Pemberdayaan Masyarakat Berbasis Masjid dalam Perspektif Dakwah Nabi SAW”, Journal 
Kamaruddin, Pemberdayaan Ekonomi Masyarakat...

of Islamic Studies and Humanities, Vol 1, No. 1. Semarang : UIN Walisongo

Hutomo, M. Y. (2000). "Pemberdayaan Masyarakat dalam Bidang Ekonomi: Tinjauan Teoritik dan Implementasi”. Naskah.

Meuleman, Johan H. (2002), "Islam in the Era Globalization: Muslim Attitudes Towards Modernity and Identity", London: Routledge

Kamaruddin dkk. (2011), "Revitalisasi Fungsi Masjid Dalam Pemberdayaan Umat di Aceh, Studi kasus di Banda Aceh Besar, Aceh Tengah dan Aceh Tamiang”. Banda Aceh: Pusat Penelitian IAIN Arraniry

Setiana, Lucie. (2005), "Teknik Penyuluhan dan Pemberdayaan Masyarakat”, Jakarta: Ghalia Indonesia

Shihab, M. Quraish. (1996), “Wawasan AlQur'an”, Bandung: Mizan

Maisaroh, S., \& Sukhemi, S. (2011). "Pemberdayaan Masyarakat Melalui Pengembangan Budaya Kewirausahaan Untuk Mengurangi Pengangguran Dan Kemiskinan”. JEJAK: Jurnal Ekonomi Dan Kebijakan, 4(1), 23-33. https://doi.org/10.15294/JEJAK.V4I1. 4638. Semarang : Universitas Negeri Semarang
Rasdi, Mohammad Tajuddin Haji Mohammad. (1998), "The Mosque as a Community Development Centre: Programme and Architectural Guidelines for Contemporary Muslim Societies", Johor Bahru: UTM

Tuhuleley, Said. (2002). "Masjid, Rekonstruksi Wawasan Kemanusiaan, dan Pembangunan Ummat", Seminar Nasional Milad Masjid Syuhada, Yogyakarta.

Gazalba, Sidi. (1989). "Mesjid : Pusat ibadat dan kebudayaan islam”, Jakarta : Pustaka Al-Husna

Kurniawan, Syahalul. (2014), "Masjid dalam Lintasan Sejarah Umat Islam”, Jurnal Khatulistiwa-Journal of Islamic Studies, Vol. 4, No.2. Pontianak : IAIN Pontianak

Hidayat, Wahyu Panca dan Lestari, Puji, "Strategi Pengembangan Jama'ah Masjid Jogokariyyan Yogyakarta Sejak 2003-2013". Yogyakarta : Universitas Negeri Yogyakarta.

The World Bank. (2001). "What Is Empowerment? Development”.

Wyer, P., \& Mason, J. (1999). "Empowerment in small businesses". Participation and Empowerment: An International Journal. https://doi.org/10.1108/146344499102 98169. United Kingdom : Emerald Publishing 